Paideusis

\title{
“The Play's the Thing”: Mathematization as Dramatization
}

\section{Dan Mellamphy and Nandita Biswas Mellamphy}

Volume 17, Number 1, 2008

URI: https://id.erudit.org/iderudit/1072466ar

DOI: https://doi.org/10.7202/1072466ar

See table of contents

Publisher(s)

Canadian Philosophy of Education Society

ISSN

0838-4517 (print)

1916-0348 (digital)

Explore this journal

Cite this article

Mellamphy, D. \& Biswas Mellamphy, N. (2008). “The Play’s the Thing”:

Mathematization as Dramatization. Paideusis, 17(1), 35-44.

https://doi.org/10.7202/1072466ar
Article abstract

Mobilizing prevalent themes in the fields of mathematics education, literary criticism, and philosophy, this paper contextualizes 'the mathematical', 'mathematical thinking', and 'mathematical pedagogy' with respect to ancient Greek concept of mathesis, modern notions of mathematical agency, the Keatsian concept of negative capability, and the analogy of 'staging' a dramatic/mathematical 'play'. Its central claim is that mathematization is dramatization - that learning mathematics (indeed, learning to learn, which is what the Greek mathesis actually means) is an activity of setting things up and (in this 'set' or 'setting') allowing things to play out (e-ducere). Beginning with Paul Ernest's identification of the difference between absolutism and fallibilism in the philosophy of math education, and incorporating concepts from Pythagoras, Hippasus, Heraclitus (the 'ancients'), Descartes, Kant, Keats (the 'moderns'), as well as Freud, Heidegger, and Badiou ('nos prochains', to quote Klossowski ), we argue that 'mathematical knowledge' cannot be understood simply within the framework of logicism, formalism, or even simply as an epistemological articulation. Rather, we endeavour to show that the process of 'learning mathematically' allows us to gain insight into the foundations of 'being' itself (i.e. ontology). Learning to learn (mathesis) proceeds, as such, by way of staging and playing-out the half-known or unknown (the ill-seen and ill-said) in the hopes of uncovering the mystery (Greek myesis) at the heart of things. (c) Dan Mellamphy, Nandita Biswas Mellamphy, 2008

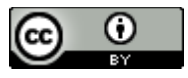

This document is protected by copyright law. Use of the services of Érudit (including reproduction) is subject to its terms and conditions, which can be viewed online.

https://apropos.erudit.org/en/users/policy-on-use/ 


\title{
"The Play's the Thing": Mathematization as Dramatization
}

\author{
DAN MELLAMPHY \\ University of Western Ontario, Canada
}

\author{
NANDITA BISWAS MELLAMPHY \\ University of Western Ontario, Canada
}

\begin{abstract}
Mobiliving prevalent themes in the fields of mathematics education, literary criticism, and philosophy, this paper contextualizes 'the mathematical', 'mathematical thinking', and 'mathematical pedagogy' with respect to ancient Greek concept of mathesis, modern notions of mathematical agency, the Keatsian concept of negative capability, and the analogy of 'staging' a dramatic/mathematical 'play'. Its central claim is that mathematization is dramatization — that learning mathematics (indeed, learning to learn, which is what the Greek mathesis actually means) is an activity of setting things up and (in this 'set' or 'setting') allowing things to play out (e-ducere). Beginning with Paul Ernest's identification of the difference between absolutism and fallibilism in the philosophy of math education, and incorporating concepts from Pythagoras, Hippasus, Heraclitus (the 'ancients'), Descartes, Kant, Keats (the 'moderns'), as well as Freud, Heidegger, and Badiou ('nos prochains', to quote Klossowski'), we argue that 'mathematical knowledge' cannot be understood simply within the framework of logicism, formalism, or even simply as an epistemological articulation. Rather, we endeavour to show that the process of 'learning mathematically' allows us to gain insight into the foundations of 'being' itself (i.e. ontology). Learning to learn (mathesis) proceeds, as such, by way of staging and playing-out the balf-known or unknown (the ill-seen and ill-said) in the hopes of uncovering the mystery (Greek myesis) at the heart of things.
\end{abstract}

\section{Number Befor(e)word: The Question of 'the Mathematical'}

The interdependence between mathematics and social forces has become a subject of vital importance in the field of mathematics education, made possible in no small part by the emergence of critical discourse about the constructed, political and linguistic nature of mathematical knowledge. Scholars have argued that there are at least two contending paradigms with regard to the nature of mathematical knowledge: the absolutist and the fallibilist perspectives. The former views mathematics as an "absolute, certain and incorrigible body of knowledge"; ${ }^{2}$ the latter views mathematical knowledge as culturally constructed and therefore subject to historical change. In the absolutist paradigm, exemplified by such 20th-century movements as Logicism and Formalism, although new theories and truths may be added to the repertoire of human discovery, mathematics is ultimately universally valid, value-free, and as

\footnotetext{
${ }^{1}$ Pierre Klossowski, Sade: mon prochain (Paris: Éditions du Seuil, 1947).

2 Paul Ernest, 'What is the Philosophy of Mathematics Education?' Philosophy of Mathematics Journal 18 (2004), 8.

(C) Copyright 2008. The authors, Dan Mellamphy and Nandita Biswas Mellamphy, assign to Paideusis the right of first publication and educational and non-profit institutions a non-exclusive license to use this document for personal use and in courses of instruction provided that the article is used in full and this copyright statement is reproduced. Any other usage is probibited without the express permission of the authors.
} 
such, "[it] is a body of absolute and certain knowledge."3 In contrast, the fallibilist paradigm, influenced largely by Social Constructivism, "does not reject the role of logic and structure in mathematics, just the notion that there is a unique, fixed and permanently enduring hierarchical structure." 4 Mathematical thinking is as much subject to human fallibility and linguistic construction as any other realm of human activity: "mathematical language is a part of our language-games, which themselves are contingent and based upon our linguistic conventions that have developed as forms of community agreement." 5

The idea that mathematical knowledge is not independent of letters and words was a fundamental insight of western antiquity as well. For the ancient Greeks, ta mathemata, 'the mathematical', meant the same thing as 'learning' in general. ${ }^{6}$ As Thomas McFarlane notes,

In many ancient languages (e.g. both Hebrew and Greek) the same symbols were traditionally used for both numbers and letters. Thus, the sacred scriptures were not only expressions of vowels and consonants. They were also expressions of number and order. The vibrational qualities of their sounds have a corresponding numerical quantity that represents its particular order or logic. The logos is both qualitative and quantitative meaning. Thus, the poesis of the world is not a random creation, but is an ordered arrangement and adornment, a cosmos. And the ordering principle of this cosmos is the logos, the Word that is also Number. Thus, it is said in the Pythagorean tradition that 'Number is the principle, source, and root of all things', which is to emphasize the ordering aspect of the Word. ${ }^{7}$

If mathematical thinking can be (and historically has been) understood more generally as learning and as a fundamental human activity, then what implications might this have for mathematics education and pedagogy? Indeed, what exactly does one learn when one learns mathematics (in both its general and specific senses)? And are the basic elements or building-blocks of mathematics (numbers) akin to linguistic elements or building-blocks (letters)? If we assume that 'letter' is prior to 'word' (the condition for any 'statement'), then could 'number' not be considered to be prior to any 'mathematical statement'? And if so, what are these basic elements ('letters' and 'numbers')? What, if not 'statements', do they express? In what follows, we will argue that the mathematical (qua mathesis) is ontologically prior to any epistemological statement expressed in numerical formulations or alphabetical phrasings. Learning at the most basic level (mathesis) proceeds by way of that which is only balf-known, barely-known, near-unknowable.

\section{Negative Capability: ta Mathemata and the theatrum of Mathesis}

In his famous letter of 21-12-1817, the celebrated English poet John Keats described the capacity to "go on" in the face of partial knowledge (i.e. of partial ignorance), to "proceed by aporia" as Samuel Beckett would say (in his aptly-titled L'Innommable: The Unnamable), as being the signature characteristic of poetic sensibility. Keats called this capacity "negative capability - that is, when a man is capable of being in uncertainties, mysteries, doubts, without any irritable reaching after 'fact' and 'reason'." Linking Keats' concept to the philosophical tradition of the ancient Greek Pre-Socratics, the poet and scholar Charles

\footnotetext{
3 Paul Ernest, 'Social Constructivism as a Philosophy of Mathematics: Radical Constructivism Rehabilitated?' bttp://www.ex.ac.uk/ PErnest/soccon.htm.

${ }^{4}$ Paul Ernest, 'What is the Philosophy of Mathematics Education?' Philosophy of Mathematics Journal 18 (2004), 8, 9.

5 Michael Peters, 'Wittgenstein, Education and the Philosophy of Mathematics', Theory and Science 3.2 (Winter 2002) bttp:/ / theoryandscience.icaap.org/ content/vol003.002/peters.html.

6 For an extensive commentary on the notion of 'mathematical thinking' in the ancient Greek natural philosophers, see Martin Heidegger's seminal study, What is a Thing? (Chicago: Henry Regnery, 1967).

7 Thomas McFarlane 'The Mathematical Poetics of Enlightenment', IntegralScience.org (2000), http://www. integralscience.org/mathpoetics. html.
} 
Olson associates negative capability with the dictum of Heraclitus that "man is estranged from that with which he is most familiar."8

By 'negative capability', Keats did not intend to signify that which cut off intellectual enterprise, but rather, "an intention to make room in the life of the mind." 9 The notion of 'negative capability', as such, seems to be significant for the study of learning and teaching: in order to no longer be estranged from that with which we are most familiar, we have to be negatively capable - that is, we must be able to function without the full picture. Pippa Carter and Norman Jackson even posit a possible connection between Keats' poetic notion of negative capability and Immanuel Kant's philosophical notion of 'negative presentation', arguing that "the pursuit of certainty within a framework of the possibility of achieving it leads invariably to inflexibility and to the failure to recognize opportunities, potential benefits, other solutions to problems, and solutions to other problems, offered by the very ambiguity and uncertainty that are so feared." 10

Foreshadowing Whitehead's famous dictum that 'ignorance of ignorance is the death of knowledge', Keats argued that the ability to work with the half-known, with partial knowledge, without taking such negativity - the unknown 'facts' or 'reasons' - as a positive incapacity, was the royal road to genius. Freud would have called this road the path of durcharbeiten: literally a "working through" difficult, repressed, traumatic "blockages" (cf. 'Errinern, Wiederholen und Durcharbeiten', 'Remembering, Repeating and Working-Through', in the Internationale Zeitschrift für ärtztliche Psychoanalyse 2, 1914:485-490).

More recently, the philosopher Alain Badiou has suggested that such a power as that of Keatsian negative capability or Freudian working through can "perhaps [be] recognized" in the mathematical concept of "forcing," which was Paul Cohen's great contribution to mathematical theory. "Forcing," explains Badiou, "is the point at which a [half-known/partially-known] truth, although incomplete, authorizes anticipations of knowledge". ${ }^{11}$ Through the force or "forcing" of durcharbeiten (Keats's "negative capability"), the unknown or unfamiliar - the uncertain, the mysterious, that which is riddled with doubt-is brought into play, allowed onto the stage or into the theatre of "theory and practice" precisely "as" this theatre, stage, or setting. The unknown is thus acknowledged as the ground (the 'road' again, or 'path') of ta mathemata, the (open) stage or setting of 'learning' in general. To stride this stage, to perform upon this stage, is to be an actor: one who acts 'as if' the (unknown/uncertain) world's a stage, one who 'is' (or as Keats says, "is capable of being") "in uncertainties, mysteries, [and] doubts, without any irritable reaching after 'fact' and 'reason'."

Ta mathemata - and mathesis understood as 'learning' in general, coming to know things that 'matter' or 'count' in particular - necessitates drama (dramatization), in other words. 'Drama' itself simply means an 'act' or 'performance' (the Greek word for 'play', 'deed', or 'action'). Descartes, who distinguished "learning in general" from the specific discipline of "mathematics" precisely by way of the word mathesis ${ }^{12}$ (using mathesis and/or mathesis universalis as his term for general disciplina, ${ }^{13}$ understood as

\footnotetext{
${ }^{8}$ Charles Olson, The Special View of History: Lectures at Black Mountain, 1956 (Berkeley: Oyez, 1970), 29. Olson is referring to the Diels-Kranz fragment 72, Bywater fragment 93, Marcovich fragment 4.

${ }_{9}^{9}$ Nathan Scott Jr., Negative Capability (New Haven: Yale UP, 1969), xiii.

10 Pippa Carter and Norman Jackson, 'Negation and Impotence', In the Realm of Organization: Essays for Robert Cooper (London: Routledge, 1998), 205-206. "[T] he very ambiguity and uncertainty that are so feared" are the impetus of philosophy (the love/pursuit of wisdom) according to the Theaetetus (155d3; also cf. Aristotle in the Metaphysics, 2.982b12-13), this "fear" being the ground mood or grundstimmung of thaumazein ("awe" and "wonder"). Oliver Ranner notes that, philosophically speaking, thaumazein is to be understood as the condition of "being in aporia": "being in uncertainties, mysteries, doubts, without any irritable reaching after 'fact' and 'reason'," as Keats would say ("to be in aporia": cf. Ranner's abstract, 'Plato and Aristotle on the Origin of Philosophy', bttp:/ / www.apaclassics.org/AnnualMeeting/03mtg/abstracts/ ranner.htmo).

11 Alain Badiou, 'Truth, Forcing, and the Unnamable', Theoretical Writings (London: Continuum, 2004), 127.

12 "A late sixteenth-century work that Descartes had certainly read, Clavius's book on the Elements of Euclid (1589; $2^{\text {nd }}$ edition: 1603), speaks of the need to know 'the mathematical sciences'," explains David Sepper in his
} 
the regulae ad directionem ingenii:14 the 'rules of the game,' so to speak, by which one learns how to learn), went as far as to say "ut comcedi, moniti ne in fronte appareat pudor, personam induunt, sic ego hoc mundi teatrum conscensurus, larvatus prodeo": just as actors, in order to conceal their shame (the shame-pudor-of 'acting', of putting on an 'act'), are advised to put on a mask (personam), so likewise, striding out upon the Theatre of the World's great Stage (mundi teatrum conscensurus), "I advance masked" (larvatus prodeo). ${ }^{15}$

According to Descartes, learning is, it seems, a rather shameful (shame-faced) activity: a 'playingaround', a childish or child-like 'pretense' (pretending). The theoretical 'theatre' here-the theatrum of mathesis — is thus both a kind of stage-play and something along the lines of child's play. What is 'acted out' (this phrase itself being a workable translation of $e$-ducere, 'education') is the actus (Latin 'doing') or agere (Latin 'to do' or 'to set in motion') derived from the Greek agon ('conflict' or 'stuggle') and agogos (one who 'leads' or 'forges' the way), or more specifically and pointedly the pais- or paidos-agogos: the agogos (the 'forging ahead') of the pais or paidos ('youth', 'youthful' or 'child-like' one). Mathesis_learning in general, and mathematics in particular-is pedagogical: it comes down to the act (the actions) of a child at play or of committed play-acting (role-playing, if you will; "a child playing," as Heraclitus says ${ }^{16}$ ).

The link between the Cartesian insight regarding learning as an 'acting out' or 'playing out' and the Keatsian insight regarding the importance of 'negative capability' is also something the pedagogue and playwright John Mighton acknowledged when we had proposed it to him several years ago; indeed, "partial understanding is not a bad thing in mathematics," he explained. "There's an idea now, which I think is widespread, that if you introduce a kid to something that they don't understand completely, can't explain completely, deduce all the consequences of, 'discover', then they're not developmentally 'ready' for that, and shouldn't even start. Not only does this not reflect actual mathematical practice, but I don't think it reflects how kids actually learn, because quite often kids only have a partial understanding of things, and they work at it and work at it and work at it and one day the understanding emerges. [...] This is what I call 'emergent intelligence' [...]; "sometimes actual practice with the rule and using it without the full understanding not only gets kids excited about being able to do the thing, but mysteriously 'opens up' the understanding. This is why I think understanding 'emerges': you don't suddenly understand mathematics-especially at higher levels. Perhaps when you get to higher levels the things at the lower levels become more coherent and complete, but you always realize that there is a mystery at the heart of things." 17

study Descartes's Imagination: Proportion, Images, and the Activity of Thinking. "Descartes's 'mathesis' in fact radicalizes the admonition: learn not 'mathematics' but the foundation of everything that is learnable" (Berkeley: University of California Press, 1996), 150n.22.

13 "Descartes notes that 'mathesis' amounts to the same thing as 'disciplina', discipline," writes Sepper in the study previously footnoted (151); and in the fourth of his Regulae ad directionem ingenii he explained that "[the] demand, made by ancient thinkers, that one learn 'mathesis' -- the way of cognitive discipline -- as a prerequisite to the study of wisdom" (indeed the demand that was carved above the entrance to the Platonic Academy, "radicalized" by Descartes, op.cit.) was put forth precisely "because it is the simplest and most necessary [regulum] of all for preparing the ingenium" (150).

14 cf. René Descartes, Regulae ad directionem ingenii, Oeuvres de Descartes, Vol. X (Paris: J. Vrin, 1956) and Regulae ad directionem ingenii: Règles utiles et claires pour la direction de l'esprit en la recherche de la vérité (The Hague: Martinus Nijhoff, 1977), under 'References', below.

${ }^{15}$ René Descartes, 'Praeambula' (Cogitationes Privatae), Oeuvres de Descartes, Vol. X, (Paris: J. Vrin, 1956), 213.

16 The "child playing [...] has a kingly (sovereign) power," he explains in Diels-Kranz fragment 52, Bywater fragment 79, Marcovich fragment 93.

17 Dan Mellamphy and Nandita Biswas Mellamphy, 'trialogue' with John Mighton, Fields Institute for Mathematical Research, October 2005. 


\section{Mathesis and Myesis: The Mystery at the Heart of 'the Mathematical'}

The idea that understanding "emerges" and "opens up" in the process of following a rule or role, of playing [by] the rules of the game or [by] the roles of the drama (dramathematics), is one reflected in the notions of negative capability (as opposed to positive incapacity), of durcharbeiten (Beckettian "proceeding by aporia"), of forcing in set-theory, and (according to scholars such as Charles Olson, Nathan Scott, Tilottama Rajan and Christopher Bamford ${ }^{18}$ ) Heraclitean/Heideggerian ontology. "It is this"- the idea that mathesis "emerges" from "acting things out" (agere, e-ducere) - "that Heraclitus meant when he laid down the law that was vitiated by [Plato and] Socrates and only restored by [Keats and] Rimbaud," that we are estranged from that which is most familiar to us. ${ }^{19}$ Making the unfamiliar familiar, treating the unfamiliar as if it were familiar- "forcing" it, if you will, but not by one's own force. Rather, by the force of the unfamiliar (the "estranged") as such-allowing the strange, uncertain and unknown (unfamiliar) to 'be', we are brought to the brink of the ontos (ontology), the mystery at the heart of things (Heidegger would hearken back to Meister Eckhart's abgeschiedenheit and gelassenheit in order to explain this process, this uncanny 'active passivity'). ${ }^{20}$

If ontology concerns itself with the question of what counts as (and what accounts for) 'being', then it is indeed a mathesis (qua ta mathemata). What manifests itself on the stage or in the setting of mathesis, through the very pedagogy of ta mathemata, is "that which is" (that which "counts for" or "counts as" something, nescioquid) prior to "what that is" (i.e. the quod or quoddity prior to the quid or quiddity; the quod of the quid, or nesciquid — the "je ne sais quol" of Vladimir Jankélévitch"21). "That which is" (the nescioquid) is the numerable noumenon encountered in the mathe[ma]tical opera[tion], something (nescioquid) which functions prior to epistemology. Epistemology, in this sense, is the gnomon or shadow ${ }^{22}$ of the numerable noumenon or mathe[ma]tical ontos - it takes place in the aftermath[esis]. Hence the "mystery at the heart of" mathesis is precisely mysterious: a myesis - that which the mathematicians of antiquity (and Pythagoras in particular) described as alogos ('unspeakable'; absurdum in Latin; sourd in French; silent_-deaf and mute-in English).

That which is unspeakable (alogos, absurdum), that without what (the nescioquid or je-ne-sais-quot), is the pure matheme, as Badiou points out in a recent interview; ${ }^{23}$ mathesis in this sense precedes physis (ta mathemata is distinguished from ta physika). And yet-as Pythagoras insisted and as Ernst Chladni (amongst others) has so convincingly exemplified_physis (the physical/phenomenal) is the very face/surface of mathesis (the noumenal/mathematical): the mask (larva/persona) with which, through which, and by which that which counts is actually encountered. Physis kryptesthai, wrote Heraclitus; "nature encrypts" (indeed, physis kryptesthai philei: nature loves encryption). ${ }^{24}$ Alles was tief ist liebt die Maske, wrote Nietzsche; "everything that is deep loves masks" (by extension, mathesis loves physis; physis loves to mask; physis is the mask of mathesis). ${ }^{25}$ The physical personam, the physical phenomenon, qua physis, qua personam, is precisely what the noumenal note or number "sounds through" (per-sonare).

The pedagogue-understood as the one who playfully, youthfully forges ahead—gives voice via

\footnotetext{
${ }_{18}$ Charles Olson, The Special View of History: Lectures at Black Mountain, 1956 (Berkeley: Oyez, 1970); Nathan Scott Jr., Negative Capability (New Haven: Yale UP, 1969); Tolottama Rajan, 'Keats, Poetry, and The Absence of the Work' (Modern Philology 95.3, 1998), 334-351; Christopher Bamford, 'Negative Capability' (Parabola: Tradition, Myth, and the Search for Meaning 30.2, Summer 2005), 14-20.

${ }^{19}$ Charles Olson, The Special View of History: Lectures at Black Mountain, 1956 (Berkeley: Oyez, 1970), 29.

${ }^{20}$ Martin Heidegger, Gelassenheit (Pfullingen: Nske, 1960).

${ }^{21}$ cf. Vladimir Jankélévitch, Le Je-ne-sais-quoi et le Presque-rien -- The I-Know-Not-What and the Almost-Nothing -- (Paris: Presses Universitaires de France, 1957).

22 (ombre du nombre)

23 Alain Badiou, 'Philosophy, Science, Mathematics', Collapse: An Independent Journal of Philosophical Research and Development 1 (September 2006), 19.

${ }^{24}$ Heraclitus, Diels-Kranz fragment 123, Bywater fragment 10, Marcovich fragment 8.

${ }^{25}$ Nietzsche, Jenseits von Gut und Böse (Leipzig: C.G. Naumann, 1895), \40.
} 
playful masks and is attuned to that which "sounds through" masks (the per-sonare of persona/phenomena): "the mystery" that is hidden in and as the "depth" or "heart" of things. Hence the tetractys or fourfold of mathesis according to Heidegger: in the subsection of What is a Thing entitled "Mathesis and the Mathematical', Heidegger explains that "the Greeks identify the mathematical, ta mathemata, with the following determinations": that of ta physika (natural things), that of ta poioumena (artificial things), that of ta chremata (things in use) and that of ta pragmata (useful things). Things are "learnable" (mathemata) insofar as they are natural, artificial, in use, or useful (he uses, as an example, three chairs-i.e. 'threeness' encountered in the form of three chairs - in What is a Thing?; "[w]hat 'three' is the three chairs do not tell us," he notes; "nor three apples, three cats, nor any other three things. [...] Things do not help us to grasp 'three' as such, i.e. threeness" 26$)$ : these are the phenomenal aspects or "masks" of mathesis - its epistemological epidermis, so to speak. What lies at and as the heart of such phenomena (poioumena, pragmata, physika, chremata) is a fifth-point, pempte-ouisia, or quinta-essentia: "the characterization running through these four," 27 or their "fundamental condition" qua "fundamental presupposition," 28 namely "a domain (Spielraum) where things [can] show themselves"; 29 a 'set' or 'setting', in other words — a 'stage' or 'screen' for (dis)play or projection.

This fifth point or place of fourfold frames or phenomena (the heart of phenomena's quincunx) is the set or setting in which and from which all that may be learned can be learned: it is the prologue to all possible pedagogy, and, as prologue (pre-logos, pro-logos, proto-logos), prior to all subsequent logics and logistics (logos), prior to davar (the word and worded world, in Hebrew), logos (the word and worded world, in Greek), verbum (the word and worded world, in Latin). It is, again, alogos: mute, deaf, dumbthe mute, deaf, dumb number prior to the worl]d. "Therefore," writes Heidegger (who distinguishes between the earthly ground and the worded world in his works), "we do not first get it [i.e. number, ta mathemata] out of things, but, in a certain way, we bring it already with us": it is already there, as the condition of our knowing. ${ }^{30}$

\section{$X$ Marks the Spot}

$X$ marks the spot, then: whatever one comes across (whatever one encounters) is at the point of its crossing, at the point of its encounter, something already there-something that counts, something that matters - regardless of what this thing (this matter) 'is' in the worl]d (i.e. according to the logic and logistics of the wor $[\mathrm{l} d)$. " $X$ is also the letter most commonly used in the sciences for the unknown," Mighton reminded us in our 'trialogue' of 2005; whereas on the grade-sheet it might stand as a marker of 'failure' in the sense of a 'positive incapacity', in the theatre of mathematics (mathematical opera[tion]s) it "[stands] for a different kind of ignorance: a positive and healthy ignorance-a sense of mystery." What's more, $X$ marks the spot on the stage where the actor "proceeds by aporia": "blocks" his or her progression and progresses by way of this blocking. At this suggestion, the playwright and mathematician nodded in agreement; "we're always led by the $X$-factor-the mysteries-of the questions we can't answer," he responded. "In mathematics, obviously, but in playwrighting too. My favourite playwrights are writers like Chekhov who were able to capture in even the most banal events the profound mysteries of existence and of human nature [...]: that feeling for, and that wonderful sense of, the mystery at the heart of things." $X$ marks the spot where one stands and where, standing there, one can (by way of one's negative capability, abgeshiedenheit, gelassenheit, durcharbeiten, what-bave-you) understand.

\footnotetext{
${ }^{26}$ Martin Heidegger, What is a Thing? (Chicago: Henry Regnery, 1967), 74.

${ }^{27}$ Martin Heidegger, What is a Thing? (Chicago: Henry Regnery, 1967), 70.

${ }_{28}$ Martin Heidegger, What is a Thing? (Chicago: Henry Regnery, 1967), 75.

${ }^{29}$ Martin Heidegger, What is a Thing? (Chicago: Henry Regnery, 1967), 92.

${ }^{30}$ Martin Heidegger, What is a Thing? (Chicago: Henry Regnery, 1967), 74.
} 
The underwhelming, here, can be overwhelming ("awe inspiring"). ${ }^{31}$ Chekhov in the absence of checkmarks (Chekhov in a field of ' $X$ 's, quincunxes ${ }^{32}$ ). And this spot is always already there (the prologue, the prologos): to discern it is to discern-to learn-what one already has (one's 'place', one's 'set', one's 'setting'); it is a matter of recognition, or as Olson suggests, of refamiliarization.

For Mighton, "the key" to such fundamental insights (to this recognition or refamiliarization) "is to reduce any given problem to its simplest or most elementary (elemental, essential) aspect, which usually comes down to an action. Strip the problem down to the level of action: what there is to do." Mathematization always, again, comes down to a dramatization (as we say), to an (en)action, a playing out (e-ducere). "The act, the action, is its essential feature. Anything and everything (no matter what you're looking at) can be reduced to an action. If you're going to teach reducing, start with fractions that will always divide by two, three or five, so that if the kids can count on their fingers by those they can do all their divisions and stuff. And if I introduce long division," he admits, in Thomas-Brownian (quincunxian/fifth-part) fashion, "I start with the number five because every kid can count to five. The interesting thing is, in terms of getting kids to recognize what they can do, or take steps by themselves, that you don't even have to talk about the concepts to have them see how these operations work and extend the application of their principles. If you work in these small steps sometimes the brain will suddenly organize itself to the point where it will recognize things it has never actually seen before. You start on your fingers and then, quite naturally, the fingers will point you in all sorts of different directions and allow you to grasp all sorts of different conceptions. Even with more complex problems, you can allow that recognition or that understanding to emerge, you can harness what they can do and what they can understand about the world, and sometimes (often times) there are mysterious leaps that occur, or they'll go from something that appears more mechanical to the sudden manifestation of a general insight or some kind of ability that seems beyond what you are teachingand that's what I don't think we've accounted for in math education. Math educators have done a great job of developing some very good problems and activities and such, but the question is: how do you get the kids there if they're not ready for it? - that's where we have to do more work. How do you allow kids to 'recognize' and to allow their understanding to emerge?"

The emergence of this understanding is a special kind of cognition: namely, a re-cognition. It is a matter of "recognizing" portions, proportions, patterns or parts—acknowledging their familiarity, even if, at times, it might seem to be uncanny (the familiarity of a déjà-vu); in any case, it is a matter of no longer being estranged from these portions, proportions, pattern,s or parts, no longer being estranged (as Heraclitus said) from that with which we should in fact be most familiar. What "emerges" is something that was already there-something hitherto submerged, suppressed, shut out (perhaps by dint of being merely partial, a mere portion, a point or bole in the whole). Education, e-ducere-leading or conducting out-seems (etymologically) to reflect this process of emergence or coming-forth. Indeed, education in this sense — or mathesis, more precisely — would be the veritable dramatization of this emergence: its enaction, its formation, its performance. The key, again, is to reduce any given problem to an act, an action - to its underlying drama, its theoretical/theatrical performance and/or practice, which is an essential feature of any and every mathe[ma]tical mystery. If (as Mighton said) "behind every action there is the mystery," we should add that the action itself is its embodiment (it "embodies" the mystery, in other words). Which

${ }^{31}$ Cf. the preceding footnote re: the philosophical thaumazein (the "awe" and "wonder" at and as the root - rbizome -of philo-sophia) and Rainer's related abstract at http:// www.apaclassics.org/AnnualMeeting/03mtg/abstracts/ranner.html.

32 Cf. sir Thomas Browne's rather Jorge-Luis-Borges-like Quincunxial Garden of Cyrus. In this treatise, $X$ again marks the spot, in the form/formation of quincunxes: "a continued pattern of four [points placed] at the corners of a [square or] parallelogram" with a "fifth point" (spot) at its centre (Frank Huntley, 'Introduction' to sir Thomas Browne, Hydriotaphia [Urn Burial] and The Garden of Cyrus, New York: Appleton-Century-Crofts, 1966, viii). "The addition of two fives" (for instance, counting the fingers of both hands) "is ten, or the Roman $X$, the perfect number, made of two fives -- Roman $V$ s -- joined at their apices," notes Huntley $(x)$. The $X$ or quincunx is thus the very symbolon of an encounter, confrontation, and conjunction (this at the very mid-point hidden at the heart or centre of the fourfold/square). 
brings us to the concluding statement of our 'trialogue' with Mighton: namely, that action is a kind of embodiment and that in every action there is a mystery embodied-something that theatre, in fact, exemplifies wonderfully. "Yes. And that's why, I think, theatre was once a religious event," remarked Mighton. "This explains the awe inherent in mathematics - in the sciences as well as the arts. The same religiousness or sense of mystery is at the heart of both the arts and sciences." 33 In this regard, what is most interesting is that mystery itself originally meant closed-mouthed: the mystes (the Greek word for an initiate, a student who was there to listen quietly, and to silently perform the religious rituals, the mystery's actual actions) was the one who kept his mouth closed, and mysteries were therefore (are therefore) things unspeakable, unspoken (alogos, alogon).

To talk about 'mathematics' and 'dramatics' ('mathematization' and 'dramatization') is thus in some respects to speak about the unspeakable (something so fundamental as to be prior to the wor[l]d-its very ontogenesis). The fundaments of learning are there embodied. Embodiment, however, also encrypts (physis kryptesthai: the physical encrypts ${ }^{34}$ ); and yet this encryption, this occlusion, this obscuring, in no way incapacitates the paidos-agogos: the unseen and/or unspeakable (the ill-seen and/or ill-said) is the very chthonos (ground) and bodos (path) of the paidos-agogos — the set and setting of ta mathemata, the theatrum of mathesis. To ignore this (to close one's eyes to blindness, turn a deaf ear to deafness) would amount to a fundamental incapacity with respect to education. Hence we conclude with two quotations (two ontological epigraphs), the first from A. N. Whitehead, the second from J. Lacan: "Not ignorance, but ignorance of ignorance is the death of knowledge" and "Mathematization alone reaches a 'real'."

\section{Acknowledgments}

The authors are very grateful to Dr. Heesoon Bai and the editorial board of Paideusis, and to Dr. John Mighton for the 'trialogue' in 2005 that was the original impetus for this piece.

\section{References}

Apple, Michael. Education and Power. New York: Routledge, 1985.

Badiou, Alain. 'Truth, Forcing, and the Unnamable'. In Theoretical Writings. Edited by Ray Brassier and Alberto Toscano. London: Continuum, 2004.

---. 'Philosophy, Science, Mathematics'. In Collapse: An Independent Journal of Philosophical Research and Development 1, September 2006,

Bamford, Christopher. 'Negative Capability'. In Parabola: Tradition, Myth, and the Search for Meaning 30.2, Summer 2005, 14-20.

Beckett, Samuel. The Unnamable. Translated from the Original French by the Author. New York: Grove Press, 1958.

---. Ill Seen Ill Said. Translated from the Original French by the Author. New York: Grove Press, 1982.

Borba, Marcello, and Ole Skovsmose. 'The Ideology of Certainty in Mathematics Education'. For the Learning of Mathematics 17.3, November 1997, 17-23.

Browne, Sir Thomas. Hydriotaphia (Urn Burial) and The Garden of Cyrus. Edited and introduced by F. L. Huntley. New York: Appleton-Century-Crofts, 1966.

33 Dan Mellamphy and Nandita Biswas Mellamphy, 'trialogue' with John Mighton, Fields Institute for Mathematical Research, Toronto, Canada, October 2005.

${ }^{34}$ Heraclitus, Diels-Kranz fragment 123, Bywater fragment 10, Marcovich fragment 8, previously quoted. 
Burkert, Walter. Lore and Science in Ancient Pythagoreanism. Translated by Edwin Minar Jr. Cambridge: Harvard UP, 1972.

Carter, Pippa, and Norman Jackson. 'Negation and Impotence'. In the Realm of Organization: Essays for Robert Cooper. Edited by Robert Chia. London: Routledge, 1998, 188-212.

Chladni, Ernst. Entdeckungen über Die Theorie des Klanges. Leipzig: Breitkopf und Härtel, 1787.

Descartes, René. Oeuvres de Descartes, Vol. X. Edited by Charles Adam and Paul Tannery. Paris: J. Vrin, 1956.

---. Regulae ad directionem ingenii: Règles utiles et claires pour la direction de l'esprit en la recherche de la vérité. Translated by Jean-Luc Marion, with annotations by Pierre Costabel. The Hague: Martinus Nijhoff, 1977.

Eckhart, Johannes. Breakthrough: Meister Eckhart's Creation Spirituality in a New Translation. Translated and annotated by Matthew Fox. New York: Doubleday, 1980.

Ernest, Paul. The Philosophy of Mathematics Education. London: Falmer Press, 1991.

---. 'What is the Philosophy of Mathematics Education?'. In Philosophy of Mathematics Journal 18, 2004, $1-15$.

---. 'Social Constructivism as a Philosophy of Mathematics: Radical Constructivism Rehabilitated?' http:// wnw.ex.ac.uk/ $\sim$ PEmest/soccon.htm.

Freud, Sigmund. 'Errinern, Wiederholen und Durcharbeiten'. Internationale Zeitschrift für ärtæliche Psynchanalyse 2, 1914, 485-490.

Heidegger, Martin. 'Mathesis and the Mathematical'. What is a Thing? Translated by W.B. Barton. Chicago: Henry Regnery Company, 1967, 69-76.

---. Gelassenheit. Pfullingen: Nske, 1960.

Heraclitus. The Fragments: Greek Text with a Short Commentary. Translated and edited by Miro Marcovich. Mérida: Los Andes UP, 1967.

Jankélévitch, Vladimir. Le Je-ne-sais-quoi et le Presque-rien. Paris: Presses Universitaires de France, 1957.

Keats, John. The Letters of John Keats. Edited by Maurice Buxton Forman. Oxford: Oxford UP, 1935.

Kline, Morris. The Loss of Certainty. Oxford: Oxford UP, 1980.

Pierre Klossowski, Sade: mon prochain. Paris: Éditions du Seuil, 1947.

Lacan, Jacques. Séminaire XX: Encore. Paris: Seuil, 1975.

McFarlane, Thomas J. 'The Mathematical Poetics of Enlightenment'. IntegralScience.org, http://www. integralscience.org/mathpoetics.btml.

Mighton, John. The Myth of Ability: Nurturing Mathematical Talent in Every Child. Toronto: Anansi Press, 2003.

---. 'Trialogue' with Dan Mellamphy and Nandita Biswas Mellamphy. Toronto: The Fields Institute, 2005.

Ministry of Education. Teaching and Learning Mathematics: The Report of the Expert Panel on Mathematics in Grades 4 to 6 in Ontario. Ontario: Ministry of Education of the Province of Ontario, 2004.

Nietzsche, Friedrich. Jenseits von Gut und Böse. Leipzig: C.G. Naumann, 1895.

Olson, Charles. The Special View of History: Lectures at Black Mountain, 1956. Edited by Ann Charters. Berkeley: Oyez, 1970.

Pascal, Blaise. 'Man's Disproportion' (pensée 72). Pensées. Translated by W. F. Trotter, bttp:// oregonstate.edu/instruct/phl302/texts/pascal/pensees-a.html\#SECTION\%20III.

Peters, Michael. 'Wittgenstein, Education and the Philosophy of Mathematics'. In Theory and Science 3.2, Winter 2002, http:// theoryandscience.icaap.org/content/vol003.002/peters.html.

Pythagoras. The Pythagorean Sourcebook and Library. Compiled and translated by Kenneth Sylvan Guthrie.

Grand Rapids: Phanes Press, 1987.

Rajan, Tilottama. 'Keats, Poetry, and The Absence of the Work'. Modern Philology 95.3, 1998, 334-351. 
Ranner, Oliver. 'Plato and Aristotle on the Origin of Philosophy'. Abstracts of the Annual Meeting of the American Philological Association, 2003. http://wnw.apaclassics.org/AnnualMeeting/03mtg/ abstracts/ranner.html.

Scott Jr., Nathan. Negative Capability. New Haven: Yale UP, 1969.

Simondon, Gilbert. On the Mode of Existence of Technical Objects. Translated by E. N. Mellamphy. London: The University of Western Ontario, 1980.

Sinclair, N, D. Pimm, and W. Higginson (eds). Mathematics and the Aesthetic: Modern Approaches to an Ancient Affinity. New York: Springer Verlag, 2006.

Skovsmose, Ole. Mathematical Agency and Social Theorizing. København: Skriftserie, 1999.

Whitehead, Alfred North. Process and Reality: An Essay in Cosmology (Gifford Lectures delivered at the University of Edinburgh, 1927-28). Cambridge: Cambridge UP, 1929.

\section{About the Authors}

Nandita Biswas Mellamphy is Assistant Professor of Political Theory in the Department of Political Science at the University of Western Ontario. Dan Mellamphy teaches at the Centre for the Study of Theory and Criticism, the Program in Comparative Literature, and the Department of English, UWO. The two have published collaborative essays in Foucault Studies, Janus Head (the Journal of Interdisciplinary Studies in Literature, Continental Philosophy, Phenomenological Psychology, and the Arts), and here in Paideusis (the International Journal in Philosophy of Education). 